\title{
Pengaruh model pembelajaran PBL terhadap minat dan hasil belajar level C1-C4 siswa kelas VII SMPN 2 Srumbung materi pencemaran lingkungan
}

\author{
Firdayanti Luftiana ${ }^{1^{*}}$, Hani Irawati ${ }^{2}$ \\ Pendidikan Biologi Fakultas Keguruan dan Ilmu Pendidikan, Universitas Ahmad Dahlan, \\ Jl. Jendral Ahmad Yani (Ringroad Selatan) Tamanan, Banguntapan, Bantul, \\ Daerah Istimewa Yogyakarta 55191 \\ 1 firdayantiluft97@gmail.com*; hani@pbio.uad.ac.id \\ *korespondensi penulis
}

\begin{abstract}
Abstrak
Pembelajaran yang dilakukan oleh guru di SMP Negeri 2 Srumbung dominan menggunakan metode ceramah yang mengakibatkan kurangnya minat belajar pada siswa. Kurangnya minat belajar mengakibatkan siswa mengantuk saat proses pembelajaran. Kurangnya minat dapat memberikan pengaruh terhadap hasil belajar siswa yang menjadi rendah. Penggunaan model pembelajaraan Problem Based Learning (PBL) diharapkan dapat memberikan pengaruh terhadap minat dan hasil belajar siswa. Penelitian ini bertujuan untuk mengetahui pengaruh model pembelajaraan PBL terhadap minat dan hasil belajar C1-C4 siswa kelas VII pada materi pencemaran lingkungan di SMP N 2 Srumbung.

Jenis penelitian yang digunakan yaitu quasi eksperimen. Populasi dalam penelitian adalah seluruh siswa kelas VII SMP Negeri 2 Srumbung yang terdiri dari 5 kelas berjumlah 157 orang. Pengambilan sampel dilakukan dengan cara purposive sampling dengan 2 kelas yaitu VII A sebagai kelas eksperimen dan VII B kelas kontrol. Teknik pengumpulan data dengan menggunakan observasi, kuesioner, dan tes dengan instrumen observasi, angket, dan soal pilgan. Teknik analisis data yang digunakan adalah deskriptif kuantitatif dengan bantuan SPSS 20 untuk uji prasyarat dan uji hipotesis.

Berdasarkan hasil penelitian diperoleh rata-rata hasil belajar kelas eksperimen (66,77 pretest dan 81,92 posttest) dan kelas kontrol $(65,31$ pretest dan 73,75 posttest). Rata-rata minat belajar kelas eksperimen (65,33\% awal dan $84,80 \%$ akhir) dan kelas kontrol $(65,90 \%$ awal dan $73,43 \%$ akhir). Berdasarkan hasil penelitian menunjukkan bahwa: (1) terdapat pengaruh model pembelajaran PBL terhadap minat belajar siswa asymp sig $<0,05$ yaitu 0,024 sehingga $H_{a}$ diterima. (2) Terdapat pengaruh model pembelajaran PBL terhadap hasil belajar siswa karena $t_{\text {hitung }}>t$ tabel yaitu 2,095>2,02.
\end{abstract}

Kata kunci: Problem Based Learning; Minat belajar; Hasil Belajar C1-C4; Pencemaran Lingkungan

\begin{abstract}
The most dominant learning method used by teachers in SMP Negeri 2 Srumbung is lecture or teacher's talk. This method then deprives student's interest which make them sleepy during classes. The lack of learning interest gives direct impact to their learning outcome. Therefore, the use of problem based learning method (PBL) is expected to resolve this issue. This research aims to know the impact of PBL learning model towards student learning interest and learning result of c1-c4 among students of grade VII which covers environmental pollution topic.
\end{abstract}


This is a quasi-experimental research. The population in this research is all VII graders of SMP Negeri 2 Srumbung consisting of 5 classes with a total of 157 students. The samples are taken with purposive sampling an the researcher only takes two classes. VII A class is used as experiment class and VII B class acts as control class. The data are collecter with observation, questionnaire and test with the instruments used are observation guideline, questionnaire and test questions. The data are then analysed quantitatively using SPSS 20.

The result suggested that the average score from experiment class was 66,77 (pre-test) and 81,92 (post-test). In control class the average score was 65.31 (pre-test) and 73,75 (post-test). In terms of learning interest, the average was $65,33 \%$ and $84,80 \%$ in pre-test and post-test. In control class the score was $65.90 \%$ and $73.43 \%$. This empirical findings showed that 1 ) PBL learning model give significant impact to students learning interest with asymp sig $<0.05(0.024)$ so that $\mathrm{H}_{0}$ was accepted. 2) this learning model also effects learning result because $\mathrm{t}$ count $>\mathrm{t}$ table which is $2.095>2.02$

Keywords: Problem Based Learning; learning interest; C1-C4 learning result; environmental pollution

\section{PENDAHULUAN}

IPA merupakan mata pelajaran yang mempelajari tentang alam sekitar, sehingga dapat dikaitkan ke dalam lingkungan dan diharapkan siswa dapat memperoleh pengalaman belajar secara langsung. Pembelajaran IPA biologi yang sesuai dengan tuntutan kurikulum 2013 yaitu tidak berpusat terhadap guru (teacher center) karena dapat menimbulkan kebosanan bagi siswa, guru menjadi fasilitator, motivator, dan evaluator bagi siswa sehingga hanya membantu terlaksananya kegiatan pembelajaran.

Guru di SMP N 2 Srumbung belum menerapkan model-model pembelajaran untuk membuat proses pembelajaran lebih bervariasi. Pembelajaran yang bervariasi dapat membuat siswa menjadi lebih penasaran serta siswa akan lebih tertarik terhadap pembelajaran IPA biologi. Ketika siswa tertarik dan senang melakukan pembelajaran IPA biologi, maka dapat dikatakan siswa akan menjadi lebih berminat mengikuti aktivitas pembelajaran. Menurut Slameto (2015:180) minat adalah suatu rasa lebih suka serta rasa ketertarikan kepada suatu hal atau aktivitas tertentu, tanpa ada yang menyuruh atau paksaan.

Model pembelajaran PBL adalah salah satu model pembelajaran yang dapat diterapkan dalam proses pembelajaran IPA biologi. Model pembelajaran PBL memiliki karakteristik berfokus terhadap permasalahan, siswa dituntut untuk berkomunikasi secara ilmiah, serta mendorong kemampuan memecahkan masalah siswa secara berkelompok (Shoimin, 2014:132). Menurut Al-Tabany (2015:68) model pembelajaran PBL memiliki kelebihan sebagai berikut: (1) Siswa akan lebih paham terhadap konsep, sebab siswa yang akan 
menemukan sendiri konsep tersebut, (2) Menuntun cara berpikir siswa yang lebih tinggi serta melibatkan siswa dalam pembelajaran secara aktif, (3) Pembelajaran lebih bermakna karena pengetahuan tertanam dengan skemata, (4) Dapat meningkatkan motivasi dan ketertarikan siswa terhadap pembelajaran karena siswa dapat merasakan manfaat menyelesaikan permasalahan dan mengaitkannya dengan kehidupan nyata, (5) Menjadikan siswa orang yang mandiri serta dewasa dapat menerima dan menghargai pendapat orang lain serta menanamkan sikap sosial yang positif diantara siswa, (6) Mengkondisikan siswa dalam kelompok belajar yang saling berinteraksi terhadap pembelajaran dan temannya, sehingga hasil pencapaian ketuntasan belajar siswa dapat diharapkan.

\section{METODE}

Penelitian ini termasuk dalam penelitian quasi eksperimen dengan menggunakan rancangan nonequivalent kontrol group design. Penelitian ini dilaksanakan di SMP N 2 Srumbung pada bulan April 2019 semester genap tahun ajaran 2018/2019. Teknik pengumpulan data yang digunakan yaitu observasi, kuesioner, tes. Instrumen pengumpulan data yang digunakan adalah lembar observasi, angket, dan soal. Teknik analisis data yang digunakan yaitu deskriptif kuantitatif diolah dengan menggunakan SPSS 20 dengan uji prasyarat (normalitas dan uji homogenitas) dan uji hipotesis (uji independent sampel t-test dan uji Mann Whitney $U$ ).

\section{HASIL DAN PEMBAHASAN}

\section{Keterlaksanaan Pembelajaran}

Keterlaksanaan pembelajaran meliputi dua subjek yaitu guru dan siswa. Berikut ini merupakan hasil observasi keterlaksanaan pembelajaran dalam kelas eksperimen dan kelas kontrol baik guru maupun siswa:

Tabel 1. Hasil keterlaksanaan pembelajaran (guru) kelas eksperimen

\begin{tabular}{cccccc}
\hline Kegiatan & Pembukaan & inti & Penutup & Rerata & Kriteria \\
\hline Pertemuan I & $92,85 \%$ & $100 \%$ & $100 \%$ & $97,61 \%$ & Sangat Baik \\
Pertemuan II & $95,14 \%$ & $100 \%$ & $100 \%$ & $98,38 \%$ & Sangat Baik \\
Pertemuan III & $100 \%$ & $100 \%$ & $100 \%$ & $100 \%$ & Sangat Baik \\
\hline \multicolumn{5}{c}{ Tabel 2. Hasil keterlaksanaan pembelajaran (siswa) } \\
\hline Kegiatan & Pembukaan & inti & Penutup & Rerata & Kriteria \\
\hline Pertemuan I & $87 \%$ & $87,58 \%$ & $91, \%$ & $88,52 \%$ & Sangat Baik \\
Pertemuan II & $96,28 \%$ & $91,08 \%$ & $91,75 \%$ & $93,03 \%$ & Sangat Baik \\
Pertemuan III & $98,66 \%$ & $91,33 \%$ & $82,14 \%$ & $90,71 \%$ & Sangat Baik \\
\hline
\end{tabular}


Keterlaksanaan pembelajaran pada pertemuan I, tahap pembukaan memperoleh persentase $92,85 \%$ pada keterlaksanaan pembelajaran guru dan $87 \%$ pada keterlaksanaan pembelajaran siswa. Ada beberapa langkah pembelajaran yang tidak terlaksana pada tahapan pembukaan yaitu mengecek kehadiran siswa, siswa tidak menyebutkan temannya yang tidak hadir akibatnya guru tidak mengetahui siswa yang tidak hadir. Menurut Suwarna (2006:66) kegiatan pembukaan dimaksudkan agar siswa dapat memusatkan perhatian pada hal yang akan mereka pelajari. Hal tersebut dilakukan dengan cara mengemukakan tujuan yang akan dicapai, menarik perhatian siswa, memberikan acuan, dan memberikan kaitan antara materi dan bahan yang akan dipelajari.

Kegiatan inti pada pertemuan I diperoleh persentase keterlaksanaan pembelajaran guru dan siswa yaitu $100 \%$ dan $87,58 \%$ hal tersebut menunjukan kriteria sangat baik. Pada kegiatan inti tersebut terdapat beberapa langkah pembelajaran yang belum terlaksana. Langkah-langkah yang belum terlaksana tersebut seperti kegiatan siswa bertanya, merumuskan masalah, mengumpulkan data, mengolah data, memberikan solusi, siswa melakukan presentasi dan memberikan solusi. Kegiatan bertanya bertujuan untuk memberikan kesempatan kepada peserta untuk mengetahui hal yang masih siswa tidak tahu atau siswa bingungkan. Jika siswa tidak bertanya, maka guru akan sulit mengidentifikasi apakah siswa paham terhadap materi ataukah belum. Menurut Partin (2009:3) kegiatan bertanya bertujuan untuk membangkitkan rasa ingin tahu dan minat belajar siswa, perhatian siswa menjadi terpusat pada pokok bahasan, mengetahui hal-hal yang menjadi penghambat siswa dalam belajar dll. Kegiatan bertanya juga dapat berpengaruh bagi sintak merumuskan masalah, karena ketika siswa bingung terhadap video yang ditayangkan maka kegiatan merumuskan masalah akan terhambat. Ketika siswa masih bingung terhadap video yang ditayangkan oleh guru, siswa akan kesulitan membuat rumusan masalah.

Kegiatan membuat rumusan masalah juga terdapat beberapa siswa yang tidak mengikuti sintak yang diarahkan dari guru. Kegiatan membuat rumusan masalah ini merupakan sintak pertama dari model pembelajaran PBL. Ketika siswa diberikan video tentang sebuah permasalahan tentang pencemaran lingkungan, maka siswa dituntut untuk dapat membuat rumusan tentang masalah yang terdapat dalam video tersebut. Ketika siswa tidak membuat rumusan masalah, maka akan kebingungan tentang masalah yang akan digunakan untuk berdiskusi dan yang akan dipecahkan.

Langkah pembelajaran lainnya yang tidak terlaksana adalah kegiatan mengumpulkan data dan dan mengolah data. Kegiatan mengumpulkan data akan memiliki pengaruh terhadap 
siswa, karena siswa akan kesulitan memecahkan permasalahan yang sedang didiskusikan. Ketika kegiatan mengumpulkan data dilakukan dengan baik maka siswa akan memiliki pengetahuan yang baik untuk dapat mengolah data yang sudah didapatkan. Kegiatan mengolah data juga akan berpengaruh terhadap kegiatan pengujian hipotesis. Dengan terkumpulnya data-data kemudian diolah dengan baik, maka pengujian hipotesis akan dilakukan siswa dengan mudah.

Presentasi melatih keaktifan siswa, memberikan siswa rasa keberanian dan percaya diri untuk berbicara dan mengungkapkan pendapat di depan banyak orang. Jika siswa belum mampu melakukan presentasi, maka guru harus memberikan kesempatan di pertemuan yang akan datang dengan cara menunjuk peserta. Menurut Mulyasa (2008:107-117) presentasi bertujuan untuk melatih kemampuan berpikir siswa serta dapat mengembangkan keaktifan.

Keterlaksanaan pembelajaran (siswa dan guru) kegiatan penutup pada kelas eksperimen pertemuan I menunjukan persentase keterlaksanaan pembelajaran yaitu $100 \%$ dan $91 \%$ hal tersebut menunjukan kategori sangat baik. Pada kegiatan penutup guru melaksanakan semua langkah-langkah yang terdapat dalam RPP. Sedangkan pada keterlaksanaan pembelajaran siswa terdapat beberapa langkah pembelajaran yang tidak dilakukan seperti tidak memperoleh apresiasi berupa hadiah karena siswa belum melakukan presentasi hasil diskusi. Apresiasi dapat memberikan siswa semangat dan tertarik untuk belajar. Sehingga pemberian penghargaan dapat menjadi salah satu yang dapat digunakan agar siswa bersemangat melakukan pembelajaran.

Data hasil keterlaksanaan pembelajaran siswa dan guru pada pertemuan II menunjukkan persentase yang lebih tinggi dibanding pertemuan I. Pada kegiatan pembukaan diperoleh data keterlaksanaan pembelajaran guru dan siswa yaitu 95,14\% dan 96,28\% hal tersebut menunjukan kriteria kegiatan pembukaan yang sangat baik. Terdapat kegiatan pembelajaran yang tidak terlaksana seperti guru tidak membuka pembelajaran dengan berdo'a dan siswa tidak mendengarkan apersepsi serta tujuan pembelajaran yang disampaikan guru. Apersepsi dapat memberikan siswa gambaran awal tentang materi yang akan dipelajari sehingga siswa akan lebih paham terhadap materi yang dikaitkan dengan kenyataan dalam kehidupan seharihari. Menurut Slameto (2015:36) apersepsi diperlukan untuk menghubungkan antara materi pelajaran dengan pengetahuan dan pengalaman yang telah dimiliki oleh peserta didik. Sedangkan tujuan pembelajaran diberikan kepada siswa agar siswa mengetahui apa saja yang perlu mereka capai. Hal tersebut juga sesuai dengan pendapat Sanjaya (2013:60) tujuan pembelajaran dimaksudkan agar dapat memproyeksikan apa yang harus dikuasai atau dicapai oleh siswa setelah proses pembelajaran berakhir. 
Keterlaksanaan pembelajaran guru dan siswa memperoleh persentase yaitu $100 \%$ dan 91,08\% hal tersebut menunjukan kriteria sangat baik. Pada keterlaksanaan pembelajaran guru, semua kegiatan inti terlaksana sesuai dengan RPP. Hal tersebut disebabkan guru sudah mampu menguasai kelas dengan baik, sehingga langkah-langkah pembelajaran pada kegiatan inti terlaksana sesuai RPP. Penguasaan kelas sangat dibutuhkan guru ketika melaksanakan proses belajar mengajar. Hal tersebut sesuai dengan teori menurut Djamarah dan Zain (2010:174) pengelolaan kelas bertujuan untuk mencipkan lingkungan yang kondusif bagi siswa dalam belajar sehingga tujuan pembelajaran efektif dan efisien dapat tercapai. Sedangkan pada keterlaksanaan pembelajaran siswa, terdapat beberapa langkah yang belum siswa lakukan seperti bertanya, merumuskan masalah, mengolah data, memberikan solusi dan melakukan presentasi.

Kegiatan memberikan solusi atau merumuskan rekomendasi pemecahan masalah tidak diikuti oleh beberapa siswa. Kegiatan tersebut bertujuan untuk menuntun siswa untuk belajar menyampaikan pendapat bagaimana untuk memberikan solusi atas permasalahan yang terjadi. Masalah tersebut tidak hanya dipecahkan akan tetapi dapat diberikan jalan keluar atau solusinya, sehingga sintak ini dapat memberikan pengaruh bagi siswa.

Berdasarkan data hasil keterlaksanaan pembelajaran guru pada pertemuan III, dari kegiatan pembukaan sampai dengan kegiatan penutup terlaksana dengan baik. Guru mengikuti langkah-langkah pembelajaran sesuai dengan yang telah tercantum dalam RPP. Hal tersebut dikarenakan guru dapat menguasai kelas dengan baik. Selain penguasaan kelas, seorang guru juga harus memiliki variasi metode pembelajaran serta memanajeman waktu dengan baik. Menurut Slameto (2015:96) ketika mengajar guru hanya menggunakan salah satu metode maka akan membosankan, sehingga siswa tidak tertarik terhadap pembelajaran. Variasi metode menyebabkan penyajian bahan pelajaran menjadi lebih menarik yang membuat siswa mudah menerima dan kelas menjadi hidup. Pada keterlaksanaan pembelajaran siswa kegiatan Pembukaan sampai dengan penutup, kegiatan yang belum terlaksana seperti mendengarkan motivasi, bertanya, presentasi hasil diskusi dan mendapatkan apresiasi. Terdapat beberapa siswa yang tidak mendengarkan motivasi dari guru. Motivasi sangat diperlukan bagi siswa untuk mendapatkan dorongan agar lebih bersemangat untuk melakukan pembelajaran, sehingga apabila siswa tidak mendengarkan motivasi dari guru akan berdampak bagi diri siswa. Menurut Djaali (2015:101) motivasi merupakan kondisi psikologis dan fisiologis yang ada dalam diri siswa yang dapat 
memberikan dorongan untuk melakukan kegiatan atau aktivitas guna mencapai tujuan yang diinginkan.

\section{Minat belajar}

Berikut ini merupakan data minat belajar yang diperoleh kelas eksperimen dan kelas kontrol:

Tabel 3. Rata- rata persentase skor angket minat belajar

\begin{tabular}{ccccc}
\hline \multirow{2}{*}{ Kelas } & \multicolumn{2}{c}{ Minat Awal } & \multicolumn{2}{c}{ Minat Akhir } \\
\cline { 2 - 5 } & $\begin{array}{c}\text { Persentase } \\
\%\end{array}$ & Kategori & $\begin{array}{c}\text { Persentase } \\
\%\end{array}$ & Kategori \\
\hline Eksperimen & $65,33 \%$ & rendah & $84,80 \%$ & $\begin{array}{c}\text { Sangat } \\
\text { tinggi }\end{array}$ \\
Kontrol & $65,90 \%$ & rendah & $73,43 \%$ & Tinggi
\end{tabular}

Rata-rata persentase minat belajar setelah dilakukannya pembelajaran di kelas eksperimen memperoleh kategori sangat tinggi dan pada kelas kontrol dalam kategori tinggi. Rata-rata persentase skor angket minat belajar pada kelas eksperimen lebih tinggi daripada kelas kontrol. Menurut Al-Tabany (2015:68) "model pembelajaran PBL dapat meningkatkan motivasi dan ketertarikan siswa terhadap pembelajaran" sehingga model pembelajaran tersebut dapat menambah ketertarikan (minat) siswa dalam belajar. Pada kelas yang tidak menggunakan model pembelajaran tersebut minat belajar cenderung lebih rendah karena tidak terdapat variasi dalam pembelajaran. Tidak terdapatnya variasi tersebut, dapat menjadi penyebab kurangnya ketertarikan siswa dalam belajar.

Tabel 4. Hasil uji normalitas minat belajar

\begin{tabular}{ccccc}
\hline & \multicolumn{4}{c}{ Data } \\
\cline { 2 - 6 } & \multicolumn{2}{c}{ Control } & \multicolumn{2}{c}{ eksperimen } \\
Shapiro Wilk & Pre & Post & Pre & post \\
\cline { 2 - 6 } & 0,035 & 0,028 & 0,040 & 0,045 \\
\hline
\end{tabular}

Berdasarkan uji normalitas minat belajar sebelum pembelajaran di kelas kontrol dan kelas eksperimen dengan menggunakan uji Shapiro Wilk diperoleh nilai Sig 0,035 dan Sig 0,040. Kriteria yang digunakan bahwa $\mathrm{H}_{\mathrm{a}}$ ditolak apabila nilai signifikansi $<0,05$. Maka dari itu data minat belajar siswa tidak berdistribusi normal karena $<0,05$. Sedangkan uji normalitas minat belajar sesudah pembelajaran di kelas kontrol dan kelas eksperimen dengan menggunakan uji Shapiro Wilk diperoleh nilai 0,028 dan 0,045. Sehingga dapat dinyatakan bahwa minat belajar siswa sesudah pembelajaran tidak berdistribusi normal karena $<0,05$

Tabel 5. Hasil uji homogenitas minat belajar

\begin{tabular}{cccc}
\hline Nama & Signifikansi & Kriteria & Keterangan \\
\hline Minat belajar sesudah & 0,31 & $>0,05$ & Homogen \\
Minat belajar sebelum & 0,79 & $>0,05$ & Homogen \\
\hline
\end{tabular}


Data homogenitas minat belajar siswa yaitu Sig 0,31 dan 0,79. Kriteria uji homogenitas yaitu jika nilai sig >0,05 maka Ha diterima dan data bersifat homogen karena signifikansi yaitu $0,31>0,05$ dan $0,79>0,05$. Data yang diperoleh berdistribusi tidak normal, maka data minat belajar tersebut dilakukan uji hipotesis menggunakan Mann Whitney.

Tabel 6. Hasil uji Mann Whitney

\begin{tabular}{ccc}
\hline minat belajar & Asymp sig & perubahan \\
\hline $\begin{array}{c}\text { Kontrol dan eksperimen } \\
\text { setelah pembelajaran }\end{array}$ & 0,024 & Ada perbedaan \\
\hline
\end{tabular}

Hasil uji data menggunakan Mann Whitney pada minat belajar sesudah dilakakukan pembelajaran di kelas kontrol dan kelas eksperimen adalah Asymp sig. 0,024. Kriteria uji Mann Whitney menyatakan bahwa jika asymp sig $<0,05$ maka hipotesis diterima. Berdasarkan data tersebut asymp sig 0,024 $<0,05$ sehingga terdapat pengaruh PBL terhadap minat belajar siswa. Minat belajar adalah adalah suatu rasa lebih suka serta rasa ketertarikan kepada suatu hal atau aktivitas tertentu, tanpa ada yang menyuruh atau paksaan (Slameto, 2015: 180). Minat belajar dapat ditimbulkan dengan cara melakukan pembelajaran yang lebih menarik perhatian siswa. Ketika siswa merasa tertarik dengan pembelajaran maka akan lebih senang mengikuti pembelajaran.

Minat belajar pada siswa sangat penting untuk membangkitkan semangat belajar pada siswa. Sehingga guru harus memberikan materi dengan cara-cara yang menarik dan tidak monoton seperti dengan menerapkan model pembelajaran PBL Model pembelajaran PBL memiliki karakteristik siswa menggali pengetahuannya sendiri, sehingga siswa tidak terpaku terhadap materi yang diberikan oleh guru dan siswa dapat berpengetahuan yang luas, permasalahan yang digunakan dalam kehidupan nyata sehingga siswa dapat dengan mudah memahami pembelajaran (Shoimin, 2014:130). Hal tersebut menjadi salah satu faktor bahwa model pembelajaran PBL dapat mempengaruhi minat belajar siswa. Sesuai dengan teori menurut Al-Tabany (2015:68) bahwa model pembelajaran PBL dapat meningkatkan motivasi dan ketertarikan siswa terhadap pembelajaran karena siswa dapat merasakan manfaat menyelesaikan permasalahan dan mengaitkannya dengan kehidupan nyata. Sama halnya dengan penelitian yang dilakukan oleh Muhson (2009:171-182) yang memperoleh hasil penelitian bahwa model pembelajaran PBL dapat mempengaruhi minat belajar siswa. Minat merupakan ketertarikan seseorang terhadap sesuatu sehingga mendorongnya untuk melakukan aktivitas agar mendapatkan penguasaan dan perhatian. Minat berasal dari pembawaan dan muncul adanya pengaruh dari luar. Dalam hal ini, penerapan model 
pembelajaran pada kelas ekpserimen merupakan pengaruh luar yang dapat menimbulkan minat belajar siswa. Ketika materi pelajaran menarik untuk dipelajari, siswa akan tertarik terhadap pembelajaran.

\section{Hasil belajar}

Data hasil belajar diperoleh dengan memberikan soal pretest dan soal posttest. Setelah dilakukan pretest dan posttest kepada kelas kontrol dan kelas eksperimen, diperoleh rata- rata hasil belajar siswa sebagai berikut:

Tabel 7. Rata-rata nilai pretest dan nilai posttest

kelas kontrol dan kelas eksperimen

\begin{tabular}{ccc}
\hline & Prestest & Posttest \\
\hline Kontrol & 65,31 & 73,75 \\
Eksperimen & 66,77 & 81,92 \\
\hline
\end{tabular}

Nilai pretest siswa kelas kontrol dan kelas eksperimen hampir sama menunjukan bahwa kemampuan awal siswa sebelum dilakukannya pembelajaran materi pencemaran lingkungan sama atau seimbang. Sedangkan nilai terdapat perbedaan yang cukup signifikan antara nilai posttest kelas eksperimen dan kelas kontrol. Hal tersebut disebabkan karena model pembelajaran PBL yang digunakan dapat memberikan pemahaman yang baik terhadap siswa. Hal tersebut sama seperti penelitian yang dilakukan oleh Mayasari dan Adawiyah (2015:255262) bahwa pembelajaran menggunakan model pembelajaran PBL berpengaruh positif terhadap hasil belajar siswa.

Tabel 8. Hasil uji normalitas hasil belajar

\begin{tabular}{ccc}
\hline & \multicolumn{2}{c}{ Data } \\
\cline { 2 - 3 } & kontrol & eksperimen \\
\hline Pretest & 0,057 & 0,076 \\
Posttest & 0,079 & 0,055 \\
\hline
\end{tabular}

Uji normalitas yang dilakukan untuk mengetahui data hasil belajar ini menggunakan uji Shapiro Wilk. Pada uji ini diperoleh Sig nilai posttest kelas eksperimen dan kelas kontrol yaitu 0,055 dan 0,079. Sedangkan Sig nilai pretest kelas eksperimen dan kelas kontrol yaitu 0,076 dan 0,057. Berdasarkan kriteria yang digunakan bahwa $\mathrm{H}_{\mathrm{a}}$ diterima apabila signifikansi $>0,05$ sedangkan nilai tersebut $>0,05$ maka dapat dinyatakan bahwa data hasil belajar siswa tersebut berdistribusi normal.

Tabel 9. Hasil uji homogenitas hasil belajar

\begin{tabular}{cccc}
\hline Nama & Signifikansi & Kriteria & Keterangan \\
\hline Hasil belajar posttest & 0,69 & $>0,05$ & Homogen \\
Hasil belajar pretest & 0,75 & $>0,05$ & Homogen \\
\hline
\end{tabular}


Uji prasayarat yang digunakan juga dalam analisis ini yaitu uji homogenitas. Diperoleh Sig 0,69 pada posttest dan Sig 0,75 pada pretest kedua itu >0,05 sehingga $\mathrm{H}_{\mathrm{a}}$ diterima, hal tersebut membuktikan bahwa data bersifat homogen.

Tabel 10. Hasil uji independent sampel t test prosttest kelas kontrol dan kelas eksperimen

\begin{tabular}{cccccc}
\hline Hasil belajar & Mean & T hitung & T tabel & asymp & keterangan \\
\hline $\begin{array}{c}\text { Posttest kelas } \\
\text { kontrol }\end{array}$ & 73,75 & 2,25 & 2,02 & 0,028 & $\begin{array}{c}\text { ada } \\
\text { perbedaan } \\
\text { ada } \\
\text { Posttest kelas } \\
\text { eksperimen }\end{array}$ \\
\hline
\end{tabular}

Berdasarkan uji independent sampel $t$ pada nilai pretest kelas kontrol dan kelas eksperimen menyatakan bahwa thit $>\mathrm{t}$ tabel atau 2,25 $>2,02$. Kriteria uji independent sampel $t$ menyatakan bahwa jika Jika $\mathrm{t}$ hit $>\mathrm{t}$ tabel maka $\mathrm{H}_{\mathrm{o}}$ ditolak dan $\mathrm{H}_{\mathrm{a}}$ diterima, sedangkan jika Thit $<\mathrm{t}$ tabel maka $\mathrm{H}_{\mathrm{o}}$ diterima dan $\mathrm{H}_{\mathrm{a}}$ ditolak. Maka dari itu, pada nilai posttest kelas eksperimen dan kelas kontrol terdapat perbedaan yang signifikan. Sehingga dapat dinyatakan bahwa terdapat pengaruh model pembelajaran PBL terhadap hasil belajar siswa. Hal tersebut sama seperti penelitian yang dilakukan oleh Mayasari dan Adawiyah (2015:255-262) bahwa pembelajaran menggunakan model PBM berpengaruh positif terhadap hasil belajar siswa level C1-C4. Hasil belajar kognitif yang diukur pada penelitian ini pada level C1-C4 yaitu mengingat, memahami, mengaplikasikan dan menganalisis. Pada materi pencemaran lingkungan kompetensi dasar yang harus siswa kuasi adalah sampai tahap menganalisis. Maka dari itu, peneliti membuat soal tes dari level C1-C4 yang sesuai dengan KD yang sudah ada.

Model pembelajaran PBL memiliki karakteristik siswa menjadi orang yang belajar dan menggali pengetahuannya sendiri serta permasalahan yang diberikan kepada siswa adalah permasalahan yang ada dalam kehidupan nyata (Shoimin, 2014:130). Hal tersebut dapat menjadi salah satu faktor yang menyebabkan hasil belajar siswa lebih tinggi. Siswa belajar lebih luas tentang materi yang diberikan oleh guru dan tidak hanya berpaku dengan materi guru saja. Sehingga siswa menjadi lebih berpengetahuan yang luas dan lebih paham terhadap konsep materi. Menurut Al-Tabany (2015:68) siswa akan lebih paham terhadap konsep karena siswa menemukan sendiri konsep tersebut dan pembelajaran akan lebih bermakna karena pengetahuan tersebut tertanam dengan skemata.

Materi pencemaran lingkungan menuntut siswa untuk dapat menganalisis suatu permasalahan hal tersebut terdapat di dalam KD 3.12 yaitu siswa menganalisis terjadinya pencemaran lingkungan dan dampaknya bagi ekosistem. Maka dari itu, pembelajaran dituntut 
untuk membuat siswa berpikir secara kritis bukan hanya sekedar mengingat $(\mathrm{C} 1)$, memahami (C2) dan mengaplikasikan (C3) akan tetapi siswa dituntut untuk dapat menganalisis (C4). Penggunaan model pembelajaran dapat membantu siswa untuk berpikir tingkat tinggi salah satunya dengan menggunakan model pembelajaran PBL. Menurut Al-Tabany (2015:68) Model pembelajaran PBL memiliki kelebihan dapat menuntun cara berpikir siswa yang lebih tinggi. Masalah yang terdapat dalam model pembelajaran PBL merupakan masalah dalam kehidupan nyata serta siswa dituntut untuk menganalisis permasalahan sampai memecahkan masalah tersebut, menentukan kesimpulan dan memberikan saran bagaimana pemecahan masalah. Maka dari itu, model pembelajaran PBL dapat menuntun siswa berpikir tingkat tinggi.

Karakteristik model pembelajaran PBL yang memberikan permasalahan dalam kehidupan nyata dan memberikan ruang kepada siswa untuk berdiskusi dalam kelompok kecil, dapat menambah daya tarik siswa terhadap materi pelajaran. Hal tersebut sesuai dengan teori menurut Al-Tabany (2015:68) bahwa model pembelajaran PBL dapat meningkatkan motivasi dan ketertarikan siswa terhadap pembelajaran karena siswa dapat merasakan manfaat menyelesaikan permasalahan dan mengaitkannya dengan kehidupan nyata. Minat sangat berpengaruh terhadap hasil belajar siswa. Minat belajar adalah ketertarikan siswa terhadap pembelajaran sehingga mendorong siswa untuk belajar atau melakukan aktivitas agar dapat merubah tingkah laku serta dapat menguasai pelajaran. Menurut Slameto (2015:54-72) minat menjadi salah satu faktor yang dapat mempengaruhi belajar. Siswa cenderung belajar dengan materi pelajaran yang menurutnya memiliki daya tarik. Selain faktor tersebut, hasil belajar juga dapat dipengaruhi oleh berbagai faktor lain seperti faktor internal dari dalam diri anak, mauapun faktor eksternal.

\section{SIMPULAN}

Berdasarkan hasil penelitian dan pembahasan, maka dirumuskan kesimpulan sebagai berikut: (1) Model pembelajaran PBL berpengaruh terhadap minat belajar siswa kelas VII pada materi pencemaran lingkungan di SMP Negeri 2 Srumbung. (2) Model pembelajaran PBL berpengaruh terhadap hasil belajar kognitif level C1-C4 kelas VII pada materi pencemaran lingkungan di SMP Negeri 2 Srumbung. 


\section{REFERENSI}

Al- Tabany Trianto Ibnu Badar. 2015. Mendesain Model Pembelajaran Inovatif, Progresif, dan Kontekstual. Jakarta: Prenada Media.

Djamarah, Syaiful Bahri dan Zain, Aswan. 2010. Strategi Belajar Mengajar. Jakarta: Rineka Cipta.

Djaali. 2015. Psikologi Pendidikan. Jakarta: Bumi Aksara.

Mayasari, Ria dan Adawiyah, Rabiatul. 2015. Pengaruh Model Pembelajaran Berdasarkan Masalah pada Pembelajaran Biologi Terhadap Hasil Belajar dan Keterampilan Berpikir Tingkat Tinggi di SMA. Jurnal Pendidikan Biologi Indonesia Vol 1 hal 255262.

Mulyasa. 2008. Menjadi Guru Profesional Menciptakan Pembelajaran Kreatif dan Menyenangkan. Bandung: PT Remaja Rosdakarya.

Muhson, Ali. 2009. Peningkatan Minat Belajar dan Pemahaman mahasiswa melalui penerapan Problem Based Learning. Jurnal Kependidikan penelitian inovasi pembelajaran Vol 39 hal 171-182.

Partin, Ronald. 2009. Kiat Nyaman Mengajar di Dalam Kelas. Jakarta: PT Indeks.

Sanjaya, Wina. 2013. Perencanaan dan Desain Sistem Pembelajaran. Jakarta: Kencana.

Shoimin, Aris. 2014. 68 Model Pembelajaran Inovatif dalam Kurikulum 2013. Yogyakarta: Ar-Ruzz Media.

Slameto. 2015. Belajar dan Faktor-Faktor Yang Mempengaruhinya. Jakarta: Rineka cipta.

Suwarna. 2006. Pengajaran Mikro, Pendekatan Praktis dalam Menyiapkan Pendidik Profesional. Jogjakarta: Tiara Wacana. 